\title{
Analysis of the Quality of SLR Station Coordinates Determined from Laser Ranging to the LARES Satellite
}

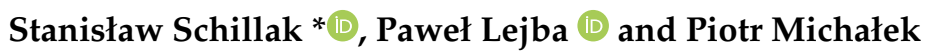 \\ Centrum Badań Kosmicznych Polskiej Akademii Nauk (CBK PAN), 00-716 Warszawa, Bartycka 18A, \\ Obserwatorium Astrogeodynamiczne CBK PAN, 62-023 Borówiec, Poland; plejba@cbk.poznan.pl (P.L.); \\ misiek@cbk.poznan.pl (P.M.) \\ * Correspondence: sch@cbk.poznan.pl; Tel.: +48-783-479-747
}

check for

updates

Citation: Schillak, S.; Lejba, P.; Michałek, P. Analysis of the Quality of SLR Station Coordinates Determined from Laser Ranging to the LARES

Satellite. Sensors 2021, 21, 737.

https://doi.org/10.3390/s21030737

Academic Editor: José M. Ferrándiz Received: 23 December 2020

Accepted: 18 January 2021

Published: 23 January 2021

Publisher's Note: MDPI stays neutral with regard to jurisdictional claims in published maps and institutional affiliations.

Copyright: (c) 2021 by the authors. Licensee MDPI, Basel, Switzerland. This article is an open access article distributed under the terms and conditions of the Creative Commons Attribution (CC BY) license (https:// creativecommons.org/licenses/by/ $4.0 /)$.

\begin{abstract}
The LARES (LAser RElativity Satellite) was built by the Italian Space Agency (ASI) and launched on 13 February 2012 by the European Space Agency. It is intended for studying the LenseThirring effect resulting from general relativity as well as for geodynamic studies and satellite geodesy. The satellite is observed by most ground laser stations. The task of this work is to determine the station coordinates and to assess the quality of their determination by comparison with the results from the LAGEOS-1 and LAGEOS-2 satellites. Observation results in the form of normal points $(396,105$ normal points in total) were downloaded from the EUROLAS Data Center for the period from 29 February 2012 to 31 December 2015. Seven-day orbital arcs were computed by the NASA GSFC GEODYN-II software, determining the coordinates of seventeen selected measuring stations. The average Root Mean Square (RMS) $(15.1 \mathrm{~mm})$ of the determined orbits is nearly the same as for LAGEOS (15.2 mm). The stability of the coordinates of each station (3DRMS) is from $9 \mathrm{~mm}$ to $46 \mathrm{~mm}$ (for LAGEOS, from $5 \mathrm{~mm}$ to $15 \mathrm{~mm}$ ) with the uncertainty of determining the coordinates of 3-11 $\mathrm{mm}$ (LAGEOS 2-7 mm). The combined positioning for the LARES + LAGEOS-1 + LAGEOS-2 satellites allows for the stability of $5-18 \mathrm{~mm}$ with an uncertainty of $2-6 \mathrm{~mm}$. For most stations, this solution is slightly better than the LAGEOS-only one.
\end{abstract}

Keywords: satellite geodesy; satellite laser ranging (SLR); reference frames; station coordinates determination; law-altitude satellite orbits; LARES and LAGEOS satellites

\section{Introduction}

The LARES (LAser RElativity Satellite) is mainly intended to study the Lense-Thirring effect resulting from general relativity [1-3]. This effect arises when a rotating massive body with a large moment of inertia drags a locally defined inertial system in its gravitational field (frame dragging). Frame dragging should exist regardless of the primary moment of inertia value (provided it is non zero). The results of this research were presented in many papers, e.g., [4-6]. Several papers describe the determination of tidal effects from the LARES $[7,8]$. The LARES can also be used in satellite geodesy [9]. The problem of including low-altitude geodesy satellites in determining the International Terrestrial Reference Frame (ITRF) has been a topic of discussion for many years [10]. The International Laser Ranging Service (ILRS) [11] is considering incorporating the LARES satellite into the ITRF development. However, there is a lack of articles that present research on these actions. The work to date containing the results of laser observations of this satellite concerns its basic applications in studying the Lense-Thirring effect. The presented work is intended to answer several important questions regarding the possible inclusion of the LARES in ITRF development. The basic questions to be answered by the work are: what is the quality of the coordinates of the stations determined from the laser measurements of the LARES, what is the difference in the results from determining the coordinates of the stations from the LAGEOS- 1 and LAGEOS-2, what is the quality of results from the combined solution LARES + LAGEOS, and can this solution be used for ITRF determination? 
Why is the LARES the most useful low-altitude geodetic satellite to co-establish the ITRF? Among the geodetic satellites, the basis for determining the coordinates of the stations are the LAGEOS-1 and LAGEOS-2. Etalon-1 and Etalon-2 satellites are also used for this purpose, but due to their high orbit $(19,000 \mathrm{~km})$ there are too few laser measurements to improve the quality of the coordinates determined from LAGEOS. The list of current passive geodetic satellites, which are in the shape of a sphere for more accurate determination of the center of mass of the satellite, is presented in Table 1.

Table 1. Satellite Laser Ranging (SLR) geodetic satellites.

\begin{tabular}{cccccc}
\hline Satellite & $\begin{array}{c}\text { Altitude } \\
{[\mathbf{k m}]}\end{array}$ & $\begin{array}{c}\text { Diameter } \\
{[\mathbf{c m}]}\end{array}$ & $\begin{array}{c}\text { Inclination } \\
{[\mathbf{d e g}]}\end{array}$ & $\begin{array}{c}\text { Density } \\
{\left[\mathbf{g} / \mathbf{c m}^{\mathbf{3}}\right]}\end{array}$ & Launch Year \\
\hline LAGEOS-1 & 5850 & 60 & 110 & 3.6 & 1976 \\
LAGEOS-2 & 5625 & 60 & 53 & 3.6 & 1992 \\
Etalon-1 & 19,105 & 129 & 65 & 1.3 & 1989 \\
Etalon-2 & 19,135 & 129 & 65 & 1.3 & 1989 \\
Ajisai & 1485 & 215 & 50 & 0.1 & 1986 \\
Starlette & 812 & 24 & 49 & 6.6 & 1975 \\
Stella & 804 & 24 & 99 & 6.6 & 1993 \\
Larets & 691 & 24 & 98 & 3.2 & 2003 \\
LARES & 1450 & 36 & 69 & 15.3 & 2012 \\
\hline
\end{tabular}

Among the satellites presented in Table 1, Ajisai's diameter is too large, causing significant increase in non-gravitational effects. Starlette, Stella [12], and Larets are too low, which causes additional drag from the atmosphere and the need to use high Earth's gravitational field coefficients, while LARES is most favorable for its use as the third satellite after the LAGEOS satellites to determine the position of stations. Hence its choice in this work. The LARES satellite is pictured in Figure 1.

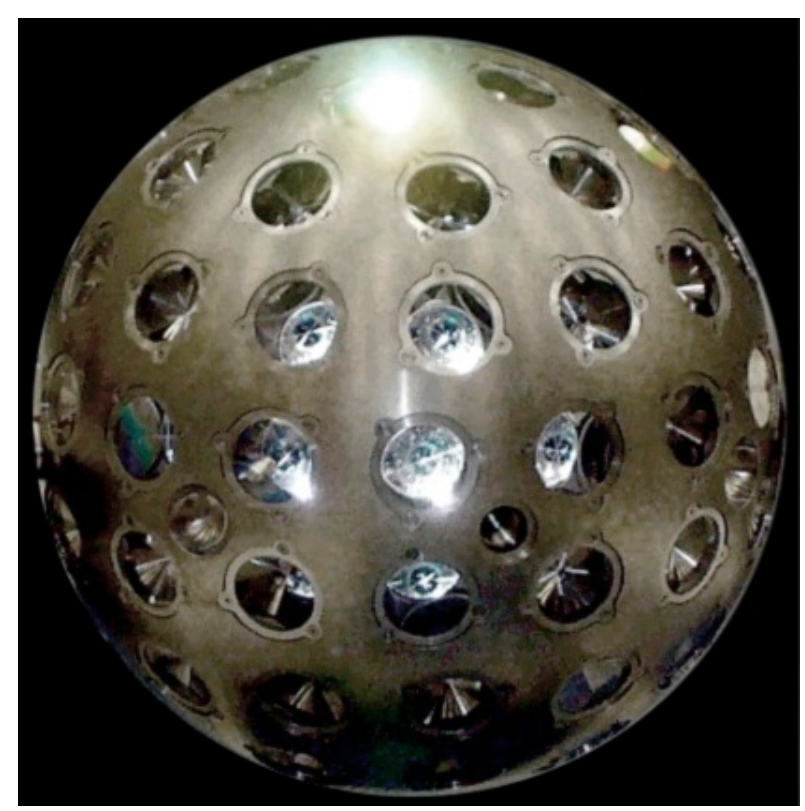

Figure 1. LAser RElativity Satellite (LARES). http:/ / www.lares-mission.com/foto.asp.

The LARES satellite, built by the Italian Space Agency (ASI), was launched on 13 February 2012 from the ESA Kourou Center in French Guiana using the Vega VV01 rocket. The satellite is moving in a circular orbit at a distance of $1450 \mathrm{~km}$ with an inclination of 69.5 degrees over a period of $1.9 \mathrm{~h}$. The satellite is only intended for laser observations. It is a sphere with a diameter of $36.4 \mathrm{~cm}$ and a mass of $386.8 \mathrm{~kg}$ (the densest object in the solar system). On the surface it has 92 corner cube retroreflectors with a diameter of 
$38.1 \mathrm{~mm}$ and a depth of $27.9 \mathrm{~mm}$ each. The satellite is observed by most ground laser stations.

The main advantages of LARES satellite for its use in satellite geodesy are as follows: its spherical shape, very well-defined center of mass, high mass (M) (low influence of nongravitational effects), small cross section (A) (low influence of non-gravitational effects), small cross-section to mass, the ratio $\mathrm{A} / \mathrm{M}=2.69 \times 10^{-4} \mathrm{~m}^{2} / \mathrm{kg}$ (the densest known object in the solar system $\left(15.3 \mathrm{~g} / \mathrm{cm}^{3}\right)$ ), its circular orbit (an eccentricity of 0.0008 ).

Its disadvantage is its low satellite orbit $(1450 \mathrm{~km})$, which entails a significant impact due to high harmonics of the Earth's gravity field (Earth's gravity field coefficients up to $100 \times 100$ ), earth albedo, and residual atmospheric drag [5].

\section{Determination of the SLR Station Coordinates}

The orbit of the LARES and SLR station coordinates have been determined using the NASA GSFC GEODYN-II orbital software [13] from the laser ranging data of 17 selected stations for the period from 29 February 2012 to 31 December 2015. SLR results were taken from the EUROLAS Data Center (EDC) in the form of 30-s normal points [14]. Weekly arcs were used in the computations, and a total of 200 orbital arcs were computed from 396,105 normal points. The average RMS of determined orbits over the entire almost four-year period was $15.1 \mathrm{~mm}$. For the same orbital arcs computed for the LAGEOS-1+ LAGEOS-2, the average RMS was nearly the same $(15.2 \mathrm{~mm})$. The models and parameters used for the LARES in the GEODYN-II orbital software are given in Table 2.

Table 2. Force models and parameters from the GEODYN-II orbital software in the LARES (LAGEOS data, if differing, are given in parentheses).

\begin{tabular}{|c|}
\hline Force Models \\
\hline Earth gravity field: EGM2008 $100 \times 100[15](20 \times 20)$ \\
\hline Earth tides: IERS conventions 2003 [16] \\
\hline Earth tide model: EGM96 \\
\hline Ocean tide model: GOT99.2 [17] \\
\hline Third-body gravity: Moon, Sun, and planets: DE403 [18] \\
\hline Solar radiation pressure coefficient: $C_{R}=1.07(1.13)$ \\
\hline Tidal constants $\mathrm{k}_{2}, \mathrm{k}_{3}$, and phase $\mathrm{k}_{2}: 0.3019,0.093,0.0$ [19] \\
\hline Earth albedo [13] \\
\hline Dynamic polar motion [13] \\
\hline Relativistic corrections [13] \\
\hline Atmospheric density model: MSIS-86 [20] (not used) \\
\hline Constants \\
\hline \multirow{4}{*}{$\begin{array}{c}\text { Earth gravity parameter (GM): } 3.986004415 \times 10^{14} \mathrm{~m}^{3} / \mathrm{s}^{2} \\
\text { Speed of light: } 299,792.458 \mathrm{~km} / \mathrm{s} \\
\text { Semi-major axis of the Earth: } 6378.13630 \mathrm{~km} \\
\text { Inverse of the Earth's flattening: } 298.25642\end{array}$} \\
\hline \\
\hline \\
\hline \\
\hline Reference Frame \\
\hline Inertial reference frame: J2000.0 \\
\hline Coordinate reference system: True of Date defined at $0.0 \mathrm{~h}$ of the first day of each arc \\
\hline Station coordinates and station velocities: SLRF2014 for epoch $2010.0[21,22]$ \\
\hline Precession and nutation: IAU 2000 \\
\hline Polar motion: C04 IERS \\
\hline Tidal uplift: Love model H2 $=0.6078$, L2 $=0.0847$ [19] \\
\hline Pole tide [13] \\
\hline
\end{tabular}


Table 2. Cont.

\begin{tabular}{|c|}
\hline Force Models \\
\hline Estimated Parameters \\
\hline $\begin{array}{l}\text { Satellite state vector (6 parameters) } \\
\text { Station geocentric coordinates (3 parameters) } \\
\text { Acceleration parameters along-track, cross-track, and radial (constant and once per revolution) } \\
\text { (14 sets per weekly solution) (2 sets per week) }\end{array}$ \\
\hline Measurement Model \\
\hline $\begin{array}{c}\text { Observations: } 30-\mathrm{s} \text { normal points from EUROLAS Data Center }(120-\mathrm{s}) \\
\text { Laser pulse wavelength: } 532 \mathrm{~nm} \\
\text { LARES center of mass correction: } 13.1 \mathrm{~cm}(25.1 \mathrm{~cm}) \\
\text { LARES cross section area: } 0.1041 \mathrm{~m}^{2}\left(0.2827 \mathrm{~m}^{2}\right) \\
\text { Mass of LARES: } 386.8 \mathrm{~kg} \text { (LAGEOS-1: } 406.965 \mathrm{~kg} \text {, LAGEOS-2: } 405.380 \mathrm{~kg}) \\
\text { Tropospheric refraction: Mendes-Pavlis model }[23,24]\end{array}$ \\
\hline Editing Criteria \\
\hline $\begin{array}{c}\text { Residual of normal points }>5 \sigma \\
\text { Cut-off elevation }<10 \text { degrees } \\
\text { Station coordinates: below } 20 \text { normal points per station and arc }+>3 \mathrm{D} \text { sigma of position } \\
\text { determination }+>\text { 3DRMS for each component North, East, Up }\end{array}$ \\
\hline Numerical Integration \\
\hline $\begin{array}{l}\text { Integration: Cowell's method } \\
\text { Orbit integration step size: } 30 \mathrm{~s}(120 \mathrm{~s}) \\
\text { Arc length: } 1 \text { week }\end{array}$ \\
\hline
\end{tabular}

From among the force models and parameters presented in Table 2, additional tests were carried out to determine the optimal coefficients of the gravitational field, the timevariable gravity, the atmospheric drag, empirical accelerations, and the corrections of satellite center-of-mass (COM) for each station. The control parameters were the orbital RMS, 3DRMS of the station coordinates, and the standard deviation of the coordinate determination. All tests were performed for Yarragadee results. The most favorable model of the gravitational field is for coefficients up to degree and order $100 \times 100$; above these values, the control parameters do not decrease and are constant. The influence of the time-variable of the gravitational field is imperceptible. The influence of atmospheric drag was not found. On the other hand, the selection of empirical accelerations is important. The best results for the LARES was obtained for all three components applied: along-track, cross-track, and radial for constant and once-per-revolution accelerations in 14 sets per weekly solution. The value of the solar radiation pressure coefficient from 1.07 to 1.13 was also checked. No significant differences in the results were found. The study did not take into account the COM corrections for individual stations [25], and a constant value of $13.1 \mathrm{~cm}$ was adopted. The aim of the work is to assess the quality of the determined station coordinates; hence the determination of the full Range Bias (RB) (without the RB part in $\mathrm{COM}$ ) for each station is important [26]. For the same reason, RB was also not included in the results.

Due to the non-convergence of the iterative process, 21 arcs were rejected, mainly due to the low number of normal points (in the most cases below 900 per arc), especially during the winter time. The list of all SLR stations that were observing the LARES in the period from 29 February 2012 to 31 December 2015 is given in Table 3. 
Table 3. List of all SLR stations which observed the LARES from 29 February 2012 to 31 December 2015. Lines in bold: core stations.

\begin{tabular}{|c|c|c|c|c|c|c|}
\hline \multirow{2}{*}{$\begin{array}{l}\text { Station } \\
\text { Number }\end{array}$} & \multirow{2}{*}{ SLR Station Name } & \multirow{2}{*}{$\begin{array}{l}\text { Number of Weekly } \\
\text { Arcs/Accepted Arcs }\end{array}$} & \multirow{2}{*}{$\begin{array}{l}\text { Number of } \\
\text { Accepted } \\
\text { Normal Points }\end{array}$} & \multirow{2}{*}{$\begin{array}{l}\text { Number of } \\
\text { Normal Points } \\
\text { Per arc }\end{array}$} & \multirow{2}{*}{$\begin{array}{c}\text { Date of First } \\
\text { Arc } \\
\text { Year-Month- } \\
\text { Day }\end{array}$} & \multirow{2}{*}{$\begin{array}{c}\text { Date of Last } \\
\text { Arc } \\
\text { Year-Month- } \\
\text { Day }\end{array}$} \\
\hline & & & & & & \\
\hline 1824 & Kiev (Ukraine) & $97 / 32$ & 1218 & 38 & 120,321 & 151,223 \\
\hline 1868 & $\begin{array}{l}\text { Komsomolsk-na- } \\
\text { Amure } \\
\text { (Russia) }\end{array}$ & $63 / 17$ & 476 & 28 & 120,509 & 151,223 \\
\hline 1873 & Simeiz (Ukraine) & $94 / 49$ & 2651 & 54 & 120,327 & 151,223 \\
\hline 1874 & $\begin{array}{l}\text { Mendeleevo } \\
\text { (Russia) }\end{array}$ & $9 / 3$ & 67 & 22 & 141,119 & 150,909 \\
\hline $\begin{array}{l}1879 \\
1886\end{array}$ & $\begin{array}{c}\text { Altay (Russia) } \\
\text { Arkhyz (Russia) }\end{array}$ & $\begin{array}{l}102 / 42 \\
88 / 37\end{array}$ & $\begin{array}{l}1676 \\
1219\end{array}$ & $\begin{array}{l}40 \\
33\end{array}$ & $\begin{array}{l}120,425 \\
120,912\end{array}$ & $\begin{array}{l}151,209 \\
151,223\end{array}$ \\
\hline 1887 & $\begin{array}{l}\text { Baikonur } \\
\text { (Kazachstan) }\end{array}$ & $76 / 33$ & 1771 & 54 & 120,502 & 150,902 \\
\hline 1888 & Svetloe (Russia) & $102 / 66$ & 4737 & 72 & 120,307 & 151,223 \\
\hline 1889 & $\begin{array}{l}\text { Zelenchukskya } \\
\text { (Russia) }\end{array}$ & $77 / 27$ & 976 & 36 & 120,404 & 151,223 \\
\hline $\begin{array}{l}1890 \\
1891\end{array}$ & $\begin{array}{l}\text { Badary (Russia) } \\
\text { Irkutsk (Russia) }\end{array}$ & $\begin{array}{l}135 / 74 \\
10 / 6\end{array}$ & $\begin{array}{c}4779 \\
190\end{array}$ & $\begin{array}{l}65 \\
32\end{array}$ & $\begin{array}{l}\mathbf{1 2 0}, \mathbf{3 0 7} \\
150,715\end{array}$ & $\begin{array}{l}\mathbf{1 5 1}, \mathbf{2 2 3} \\
151,223\end{array}$ \\
\hline 1893 & $\begin{array}{l}\text { Katzively } \\
\text { (Ukraine) }\end{array}$ & $110 / 58$ & 3218 & 55 & 120,307 & 150,916 \\
\hline 7080 & $\begin{array}{l}\text { McDonald } \\
\text { (Texas-USA) }\end{array}$ & $118 / 35$ & 1175 & 34 & 120,321 & 150,527 \\
\hline 7090 & $\begin{array}{l}\text { Yarragadee } \\
\text { (Australia) }\end{array}$ & $183 / 171$ & 51,084 & 299 & 120,307 & 151,223 \\
\hline 7105 & $\begin{array}{c}\text { Greenbelt } \\
\text { (Maryland-USA) }\end{array}$ & 171/139 & 19,400 & 140 & 120,307 & 151,216 \\
\hline 7110 & $\begin{array}{l}\text { Monument Peak } \\
\text { (California-USA) }\end{array}$ & $171 / 134$ & 13,546 & 101 & 120,307 & 151,216 \\
\hline 7119 & $\begin{array}{c}\text { Haleakala } \\
\text { (Hawaii-USA) }\end{array}$ & $153 / 93$ & 5958 & 64 & 120,307 & 151,216 \\
\hline 7124 & $\begin{array}{l}\text { Tahiti (French } \\
\text { Polinesia) }\end{array}$ & $107 / 46$ & 2205 & 48 & 120,307 & 151,209 \\
\hline 7237 & $\begin{array}{c}\text { Changchún } \\
\text { (China) }\end{array}$ & $180 / 142$ & 16,171 & 114 & 120,307 & 151,223 \\
\hline $\begin{array}{l}7249 \\
7308\end{array}$ & $\begin{array}{l}\text { Beijing (China) } \\
\text { Koganei (Japan) }\end{array}$ & $\begin{array}{l}80 / 37 \\
35 / 8\end{array}$ & $\begin{array}{c}1772 \\
367\end{array}$ & $\begin{array}{l}48 \\
46\end{array}$ & $\begin{array}{l}120,314 \\
120,307\end{array}$ & $\begin{array}{l}150,513 \\
140,305\end{array}$ \\
\hline 7358 & $\begin{array}{c}\text { Tanegashima } \\
\text { (Japan) }\end{array}$ & $3 / 1$ & 16 & 16 & 120,321 & 120,411 \\
\hline 7359 & Daedeok (Korea) & $40 / 14$ & 593 & 42 & 130,828 & 141,112 \\
\hline 7403 & Arequipa (Peru) & $153 / 78$ & 4315 & 55 & 120,307 & 151,223 \\
\hline 7405 & Concepcion (Chile) & $49 / 18$ & 650 & 36 & 120,307 & 140,319 \\
\hline 7406 & $\begin{array}{c}\text { San Juan } \\
\text { (Argentina) }\end{array}$ & $102 / 58$ & 5118 & 88 & 120,307 & 141,029 \\
\hline 7501 & $\begin{array}{l}\text { Hartebeesthoek } \\
\text { (South Africa) }\end{array}$ & $145 / 76$ & 10,004 & 132 & 120,307 & 151,223 \\
\hline 7810 & $\begin{array}{l}\text { Zimmerwald } \\
\text { (Switzerland) }\end{array}$ & $132 / 121$ & 27,844 & 230 & 120,314 & 151,118 \\
\hline $\begin{array}{l}7820 \\
7821\end{array}$ & $\begin{array}{l}\text { Kunming (China) } \\
\text { Shanghai (China) }\end{array}$ & $\begin{array}{c}30 / 17 \\
124 / 48\end{array}$ & $\begin{array}{c}609 \\
1775\end{array}$ & $\begin{array}{l}36 \\
37\end{array}$ & $\begin{array}{l}130,102 \\
120,307\end{array}$ & $\begin{array}{l}140,521 \\
151,223\end{array}$ \\
\hline 7824 & $\begin{array}{l}\text { San Fernando } \\
\text { (Spain) }\end{array}$ & $79 / 16$ & 532 & 33 & 120,418 & 151,125 \\
\hline 7825 & $\begin{array}{c}\text { Mount Stromlo } \\
\text { (Australia) }\end{array}$ & $182 / 142$ & 14,799 & 104 & 120,307 & 151,223 \\
\hline $\begin{array}{l}7827 \\
7838 \\
7839\end{array}$ & $\begin{array}{c}\text { Wettzell (Germany) } \\
\text { Simosato (Japan) } \\
\text { Graz (Austria) }\end{array}$ & $\begin{array}{c}3 / 2 \\
136 / 56 \\
169 / 141\end{array}$ & $\begin{array}{c}228 \\
3409 \\
24,257\end{array}$ & $\begin{array}{c}114 \\
\mathbf{6 1} \\
\mathbf{1 7 2}\end{array}$ & $\begin{array}{l}151,118 \\
\mathbf{1 2 0}, 328 \\
\mathbf{1 2 0 , 3 0 7}\end{array}$ & $\begin{array}{l}151,209 \\
\mathbf{1 5 1}, \mathbf{2 2 3} \\
\mathbf{1 5 1 , 2 2 3}\end{array}$ \\
\hline 7840 & $\begin{array}{l}\text { Herstmonceux } \\
\text { (UK) }\end{array}$ & $177 / 129$ & 13,663 & 106 & 120,314 & 151,223 \\
\hline 7841 & $\begin{array}{l}\text { Potsdam } \\
\text { (Germany) }\end{array}$ & $159 / 129$ & 16,040 & 124 & 120,307 & 151,223 \\
\hline $\begin{array}{l}7845 \\
7941\end{array}$ & $\begin{array}{l}\text { Grasse (France) } \\
\text { Matera (Italy) }\end{array}$ & $\begin{array}{c}73 / 31 \\
\mathbf{1 7 1 / 1 3 8}\end{array}$ & $\begin{array}{c}1643 \\
\mathbf{1 4 , 7 5 2}\end{array}$ & $\begin{array}{c}53 \\
107\end{array}$ & $\begin{array}{l}120,307 \\
\mathbf{1 2 0}, 307\end{array}$ & $\begin{array}{l}140,827 \\
\mathbf{1 5 1 , 2 2 3}\end{array}$ \\
\hline 8834 & $\begin{array}{c}\text { Wettzell } \\
\text { (Germany) }\end{array}$ & $159 / 117$ & 12,306 & 105 & 120,307 & 151,223 \\
\hline
\end{tabular}


To obtain the most accurate results, three scenarios for the selection of core stations were tested, the results of which formed the orbit of the LARES. The tests were performed using the parameters and models given in Table 2 for all 40 stations, which in the period from 29 February 2012 to 31 December 2015 were observing the LARES.

Scenario 1: 15 SLR stations selected on the basis of the quality assessment and the number of normal points of the LAGEOS were used.

Scenario 2: all 40 stations that observed the LARES during the period were used.

Scenario 3: based on the results of scenario 2, the 17 best stations were selected as the core stations for creating the orbit of the LARES.

The evaluation of the obtained results was carried out for each station based on the number of normal points, the average 3DRMS of coordinates determined, and the continuity of the observations. The best results were achieved for scenario 3 and these 17 stations were used as the core stations for further analysis (Table 3, bold).

\section{Results and Discussion}

The geocentric coordinates of the stations computed by the NASA GSFC GEODYN-II software were processed to the topocentric coordinates North, East, and Up by means of the Borkowski transformation [27]. The results include differences from SLRF2014 [22]. From these results, the average RMS was determined for each component, which in 3D characterizes the accuracy of the coordinates determined [12]. The precision of results in the form of the standard deviation of determined coordinates was also computed (Table 4). An important indicator for assessing the quantity and quality of observations for each station (percent of accepted arcs) is presented in Table 4. It points out that this percentage is slightly lower for the LARES (LA), while it is higher for most of the three satellites (LA + L12). The stations are listed in Table 4 according to their continental location. Higher quality of results for European stations is clearly visible, and is caused by a large number of stations in a small area (8 stations) and therefore a large number of measurements (this orbit segment is better determined than for other continents). It should be emphasized that the quality of observations of the stations placed on other continents is not connected with this effect, which is confirmed by the LAGEOS results for these stations (Table 4).

To compare the results of the LARES with the LAGEOS-1 and LAGEOS-2 satellites, the same weekly arcs for LAGEOS from the same stations were computed using the GEODYN-II software. Parameters and models of the orbital software are provided in [28]. The results are shown in Table 4 (L12). Higher quality of coordinates determined from the LAGEOS is clearly visible. In the case of the LAGEOS, we don't observe dependence of the quality on the continental location as in the case of LARES.

The number of normal points for the three satellites (LARES, LAGEOS-1, LAGEOS-2) for each station on the whole period of this study is presented on Figure 2. This number for each station is similar for all satellites. In addition, orbital mean RMS of normal points of each station for all satellites is on the same level (Figure 3) with an average of $15.2 \mathrm{~mm}$ (LARES) and $15.1 \mathrm{~mm}$ (LAGEOS1 + LAGEOS2) for all points of the 17 stations. An important parameter that indicates the stability of the station's range bias over several years is long-term stability. The results for each station and satellite are presented in Figure 4 and Table 5. Much better long-term stability for the LARES is visible. 
Table 4. LARES-results of station positions determination. LA: LARES, L12: LAGEOS-1 + LAGEOS-2, LA + L12: LARES + LAGEOS-1 + LAGEOS-2.

\begin{tabular}{|c|c|c|c|c|c|c|c|c|c|c|}
\hline \multirow[t]{2}{*}{$\begin{array}{l}\text { Station } \\
\text { Number }\end{array}$} & \multirow[t]{2}{*}{$\begin{array}{l}\text { SLR Station } \\
\text { Name }\end{array}$} & \multicolumn{3}{|c|}{ 3DRMS Coordinates [mm] } & \multicolumn{3}{|c|}{$\begin{array}{c}\text { Standard Deviation of The } \\
\text { Station Coordinates } \\
\text { Determination [mm] }\end{array}$} & \multicolumn{3}{|c|}{ Percent of Accepted Arcs\% } \\
\hline & & LA & L12 & LA + L12 & LA & L12 & $\mathrm{LA}+\mathrm{L12}$ & LA & L12 & $\mathbf{L A}+\mathbf{L 1 2}$ \\
\hline \multicolumn{11}{|c|}{$\begin{array}{l}\text { Europe } \\
\end{array}$} \\
\hline 1893 & $\begin{array}{l}\text { Katzively } \\
\text { (Ukraine) }\end{array}$ & 21.8 & 15.4 & 18.3 & 7.3 & 6.7 & 5.6 & 53 & 54 & 72 \\
\hline 7810 & $\begin{array}{l}\text { Zimmerwald } \\
\text { (Switzerland) }\end{array}$ & 9.5 & 5.2 & 5.2 & 3.4 & 1.9 & 1.7 & 92 & 92 & 92 \\
\hline 7839 & Graz (Austria) & 12.7 & 7.7 & 6.9 & 4.1 & 3.6 & 2.7 & 83 & 89 & 87 \\
\hline 7840 & $\begin{array}{l}\text { Herstmonceux } \\
\text { (UK) }\end{array}$ & 15.3 & 7.5 & 6.8 & 5.1 & 3.0 & 2.6 & 73 & 92 & 91 \\
\hline 7841 & $\begin{array}{l}\text { Potsdam } \\
\text { (Germany) }\end{array}$ & 14.3 & 9.4 & 8.3 & 4.7 & 4.5 & 3.1 & 81 & 81 & 84 \\
\hline 7941 & Matera (Italy) & 13.1 & 6.9 & 5.7 & 5.0 & 2.3 & 2.1 & 81 & 94 & 91 \\
\hline 8834 & $\begin{array}{l}\text { Wettzell } \\
\text { (Germany) }\end{array}$ & 11.5 & 8.1 & 7.7 & 4.6 & 3.6 & 3.0 & 74 & 71 & 81 \\
\hline \multicolumn{11}{|c|}{ North America } \\
\hline 7105 & $\begin{array}{c}\text { Greenbelt } \\
\text { (Maryland-USA) }\end{array}$ & 26.0 & 7.7 & 8.0 & 6.5 & 2.6 & 2.5 & 81 & 89 & 90 \\
\hline 7110 & $\begin{array}{l}\text { Monument Peak } \\
\text { (California-USA) }\end{array}$ & 31.2 & 10.9 & 10.3 & 7.7 & 3.2 & 2.9 & 78 & 93 & 92 \\
\hline \multicolumn{11}{|c|}{ Pacific } \\
\hline 7119 & $\begin{array}{l}\text { Haleakala(Hawaii } \\
\text {-USA) }\end{array}$ & 45.9 & 13.9 & 14.2 & 11.1 & 3.8 & 3.6 & 61 & 90 & 94 \\
\hline \multicolumn{11}{|c|}{ East Asia } \\
\hline 1890 & Badary (Russia) & 30.7 & 14.8 & 15.4 & 8.8 & 6.6 & 5.7 & 55 & 53 & 72 \\
\hline 7237 & $\begin{array}{l}\text { Changchun } \\
\text { (China) }\end{array}$ & 26.8 & 11.1 & 11.0 & 6.3 & 3.3 & 2.9 & 79 & 87 & 89 \\
\hline \multicolumn{11}{|c|}{ Australia } \\
\hline 7090 & $\begin{array}{l}\text { Yarragadee } \\
\text { (Australia) }\end{array}$ & 24.2 & 6.6 & 6.4 & 5.3 & 2.0 & 1.9 & 93 & 97 & 96 \\
\hline 7825 & $\begin{array}{l}\text { Mount Stromlo } \\
\text { (Australia) }\end{array}$ & 23.0 & 7.4 & 7.3 & 6.4 & 2.8 & 2.6 & 78 & 92 & 93 \\
\hline \multicolumn{11}{|c|}{ Africa } \\
\hline 7501 & (RPA) & 34.0 & 11.2 & 11.4 & 7.6 & 3.1 & 2.9 & 52 & 87 & 85 \\
\hline
\end{tabular}

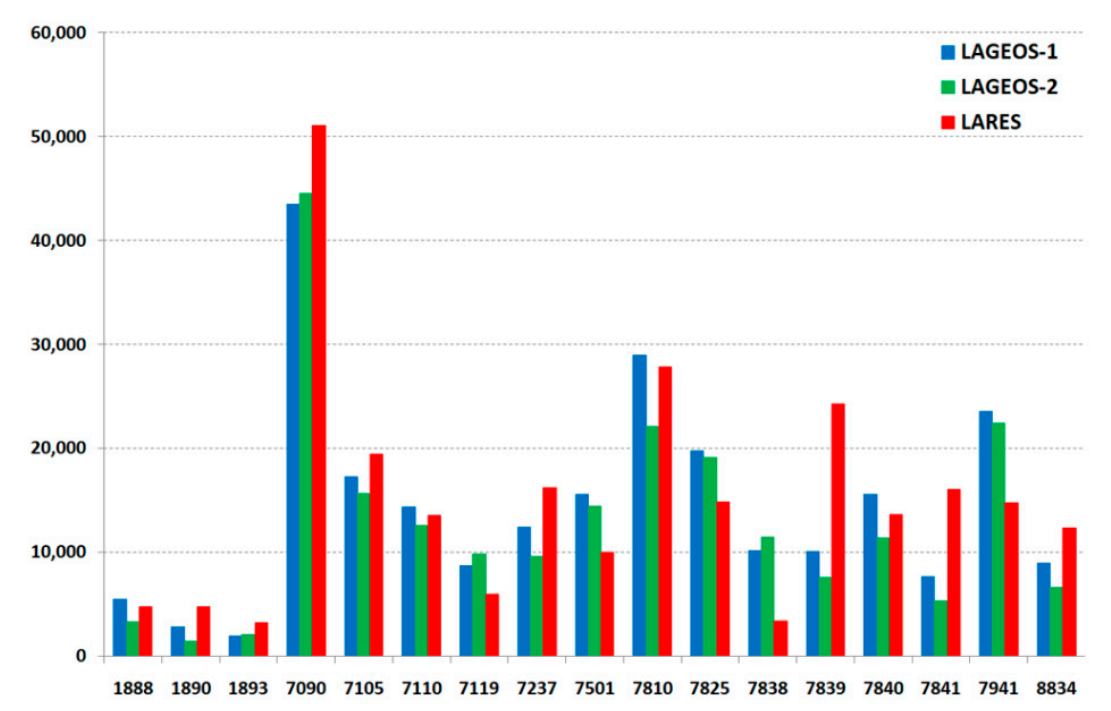

Figure 2. The number of normal points per station in the period from 29 February 2012 to 31 December 2015. 


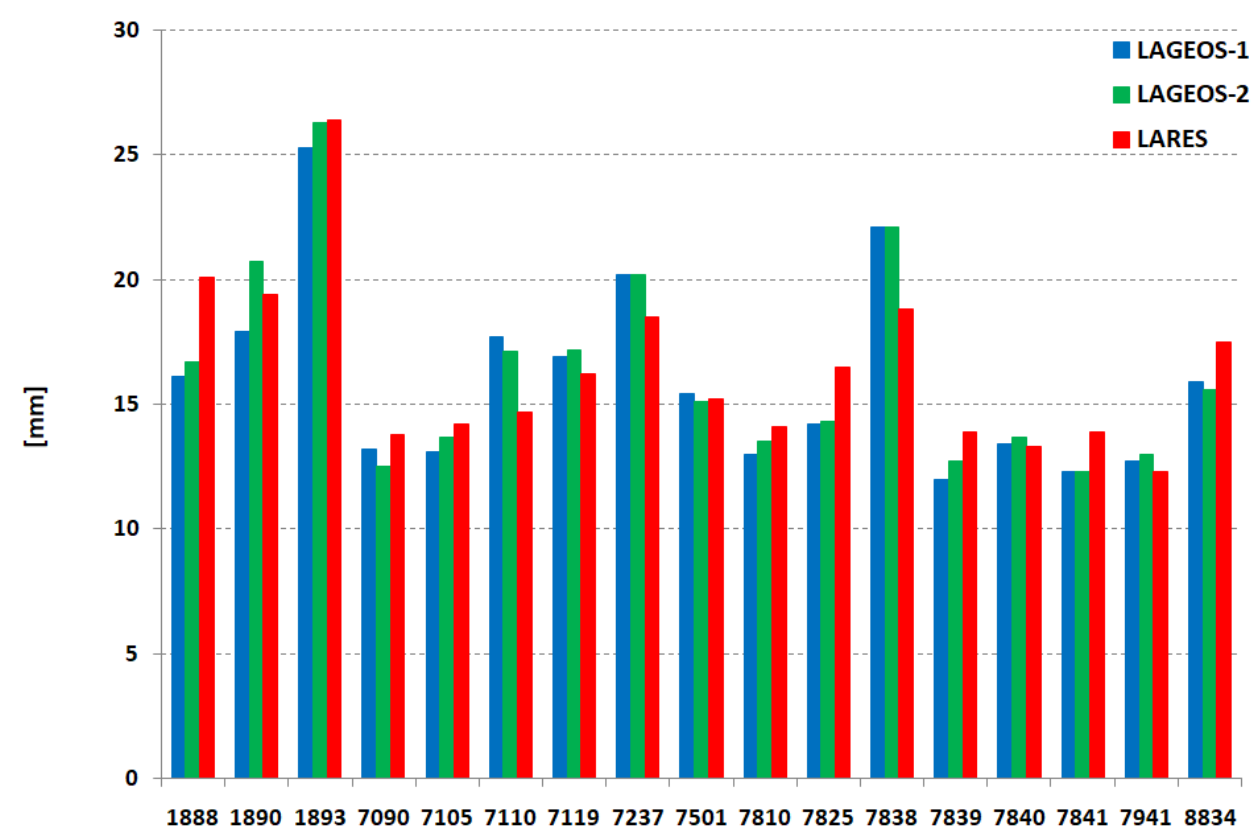

Figure 3. The average orbital RMS per station.

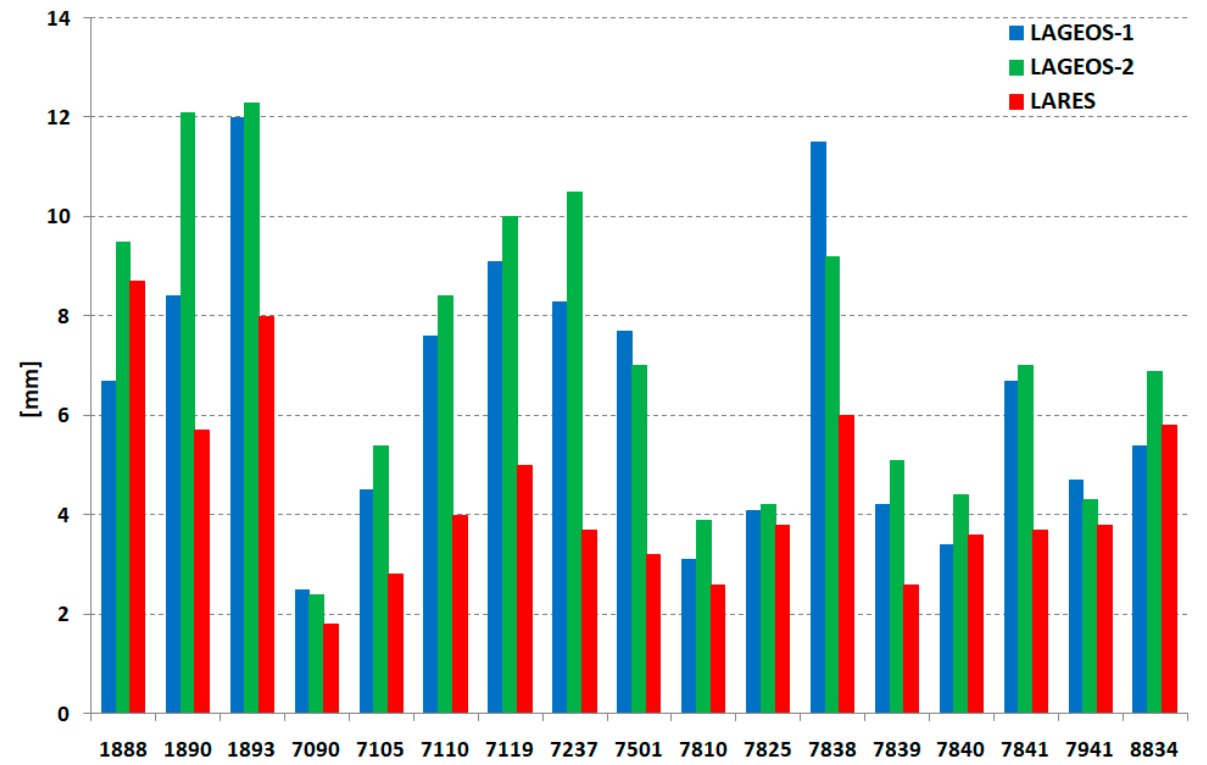

Figure 4. Long-term stability per station.

Examples of the determined North, East, and Up components for the LARES and LAGEOS satellites for the Zimmerwald and Yarragadee stations are shown in Figures 5 and 6, respectively. The average deviation from SLRF2014 and the stability of the determined position (3DRMS) are given for each component. 
Table 5. The average Range Bias, long-term stability, and orbital RMS for SLR stations.

\begin{tabular}{|c|c|c|c|c|c|c|c|c|c|}
\hline \multirow[b]{2}{*}{$\begin{array}{l}\text { Station } \\
\text { Number }\end{array}$} & \multicolumn{3}{|c|}{ LAGEOS-1 } & \multicolumn{3}{|c|}{ LAGEOS-2 } & \multicolumn{3}{|c|}{ LARES } \\
\hline & $\begin{array}{c}\text { Number of } \\
\text { Normal } \\
\text { Points }\end{array}$ & $\begin{array}{c}\text { Range Bias and } \\
\text { Long Term } \\
\text { Stability }[\mathrm{mm}]\end{array}$ & $\begin{array}{l}\text { RMS } \\
{[\mathrm{mm}]}\end{array}$ & $\begin{array}{c}\text { Number of } \\
\text { Normal } \\
\text { Points }\end{array}$ & $\begin{array}{l}\text { Range Bias and } \\
\text { Long Term } \\
\text { Stability }[\mathrm{mm}]\end{array}$ & $\begin{array}{l}\text { RMS } \\
\text { [mm] }\end{array}$ & $\begin{array}{c}\text { Number of } \\
\text { Normal } \\
\text { Points }\end{array}$ & $\begin{array}{c}\text { Range Bias } \\
\text { and Long Term } \\
\text { Stability }[\mathrm{mm}]\end{array}$ & $\begin{array}{l}\text { RMS } \\
{[\mathrm{mm}]}\end{array}$ \\
\hline 1888 & 5477 & $1.0 \pm 6.7$ & 16.1 & 3299 & $0.7 \pm 9.5$ & 16.7 & 4737 & $0.4 \pm 8.7$ & 20.1 \\
\hline 1890 & 2841 & $2.8 \pm 8.4$ & 17.9 & 1461 & $-1.4 \pm 12.1$ & 20.7 & 4779 & $-1.2 \pm 5.7$ & 19.4 \\
\hline 1893 & 1974 & $-0.9 \pm 12.0$ & 25.3 & 2071 & $-0.8 \pm 12.3$ & 26.3 & 3218 & $-11.1 \pm 8.0$ & 26.4 \\
\hline 7090 & 43,479 & $0.2 \pm 2.5$ & 13.2 & 44,535 & $-0.2 \pm 2.4$ & 12.5 & 51,084 & $1.5 \pm 1.8$ & 13.8 \\
\hline 7105 & 17,244 & $-1.0 \pm 4.5$ & 13.1 & 15,658 & $-0.4 \pm 5.4$ & 13.7 & 19,400 & $1.2 \pm 2.8$ & 14.2 \\
\hline 7110 & 14,338 & $1.7 \pm 7.6$ & 17.7 & 12,596 & $5.6 \pm 8.4$ & 17.1 & 13,546 & $3.5 \pm 4.0$ & 14.7 \\
\hline 7119 & 8703 & $2.1 \pm 9.1$ & 16.9 & 9856 & $2.9 \pm 10.0$ & 17.2 & 5958 & $1.7 \pm 5.0$ & 16.2 \\
\hline 7237 & 12,404 & $1.2 \pm 8.3$ & 20.2 & 9567 & $0.4 \pm 10.5$ & 20.2 & 16,171 & $1.7 \pm 3.7$ & 18.5 \\
\hline 7501 & 15,533 & $0.5 \pm 7.7$ & 15.4 & 14,417 & $2.7 \pm 7.0$ & 15.1 & 10,004 & $2.3 \pm 3.2$ & 15.2 \\
\hline 7810 & 28,923 & $-0.1 \pm 3.1$ & 13.0 & 22,073 & $-0.6 \pm 3.9$ & 13.5 & 27,844 & $2.9 \pm 2.6$ & 14.1 \\
\hline 7825 & 19,727 & $-1.9 \pm 4.1$ & 14.2 & 19,133 & $-1.6 \pm 4.2$ & 14.3 & 14,799 & $-2.0 \pm 3.8$ & 16.5 \\
\hline 7838 & 10,129 & $1.2 \pm 11.5$ & $\begin{array}{l}14.2 \\
22.1\end{array}$ & 11,436 & $1.8 \pm 9.2$ & $\begin{array}{l}14.3 \\
22.1\end{array}$ & $\begin{array}{c}14,179 \\
3409\end{array}$ & $0.5 \pm 6.0$ & $\begin{array}{l}10.5 \\
18.8\end{array}$ \\
\hline $\begin{array}{l}7839 \\
7839\end{array}$ & 10,103 & $-0.5 \pm 4.2$ & 12.0 & $\begin{array}{l}11,400 \\
7612\end{array}$ & $-1.7 \pm 5.1$ & 12.7 & 24,257 & $3.0 \pm 2.6$ & $\begin{array}{l}10.0 \\
13.9\end{array}$ \\
\hline 7840 & 15,554 & $4.2 \pm 3.4$ & 13.4 & 11,399 & $4.2 \pm 4.4$ & 13.7 & 13,663 & $1.1 \pm 3.6$ & 13.3 \\
\hline 7841 & 7633 & $-0.5 \pm 6.7$ & 12.3 & 5332 & $-1.2 \pm 7.0$ & 12.3 & 16,040 & $0.3 \pm 3.7$ & 13.9 \\
\hline 7941 & 23,552 & $-2.0 \pm 4.7$ & 12.7 & 22,418 & $-2.3 \pm 4.3$ & 13.0 & 14,752 & $0.2 \pm 3.8$ & 12.3 \\
\hline 8834 & 8960 & $-9.6 \pm 5.4$ & 15.9 & 6621 & $-9.2 \pm 6.9$ & 15.6 & 12,306 & $-9.2 \pm 5.8$ & 17.5 \\
\hline
\end{tabular}
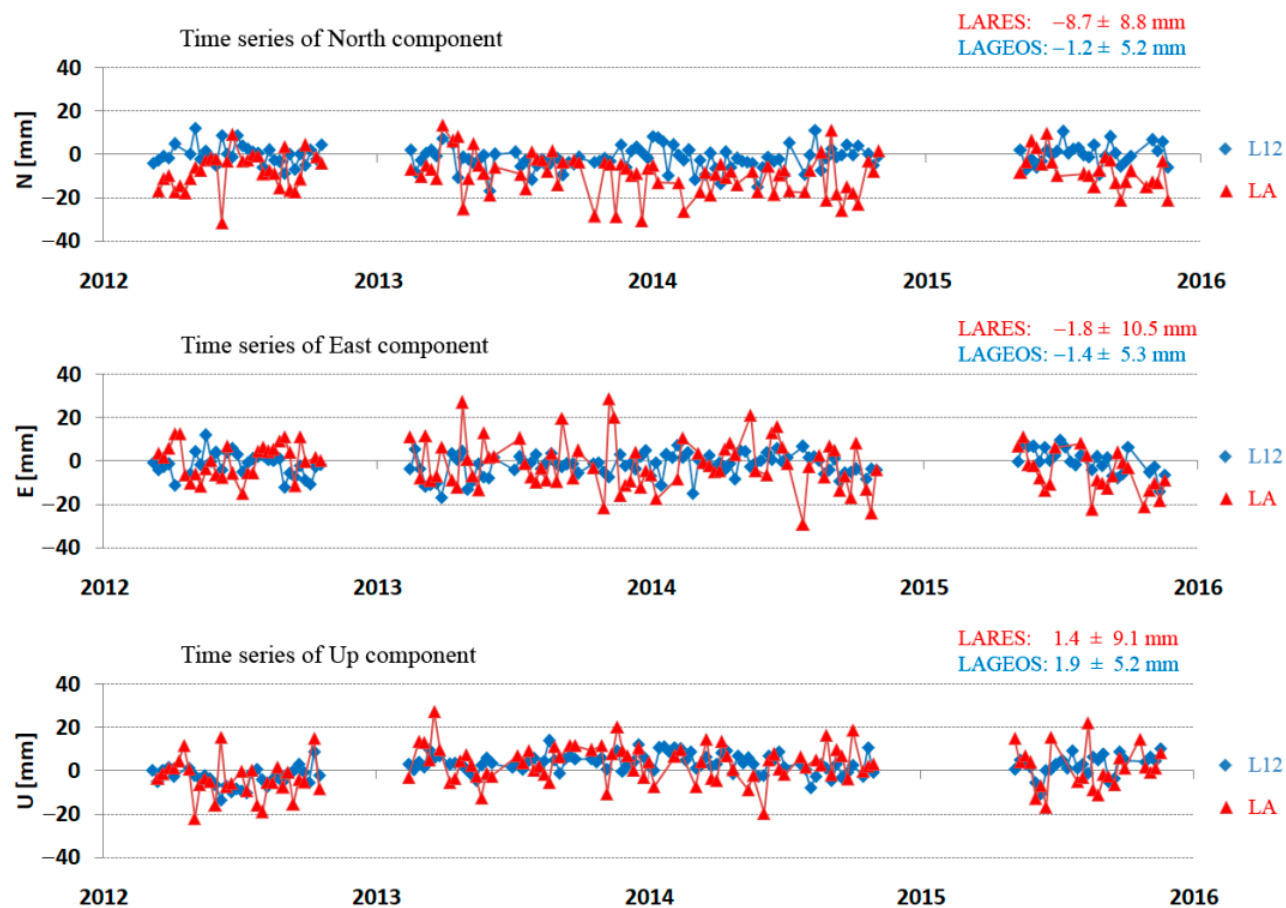

Figure 5. Time series of the North, East, and Up components for Zimmerwald station (7810) for LARES (red) and LAGEOS (blue) in the period from 2012 to 2015.

The most important element for the future inclusion of the LARES satellite in ITRF is the determination of the station coordinates from normal equations for all three satellites combined (LARES + LAGEOS-1 + LAGEOS-2).

The best parameter that determines the quality of the station coordinates is the average 3DRMS of the three components (station, position, and stability) (Equations (1) and (2)):

$$
R M S_{X}=\sqrt{\frac{\sum_{i=1}^{n}\left(X_{i}-\bar{X}\right)^{2}}{n-1}}
$$

where $i$ is the arc number, $X$ is value of component $X$ for each arc, $\bar{X}$ is the mean value of the components $X_{i}$, and $\boldsymbol{n}$ is the number of arcs. The RMS of the components $Y$ and $Z$ are 
computed analogously. The total RMS for all components (total station position stability) is computed from the Formula (2):

$$
3 D R M S=\sqrt{\frac{R M S_{X}^{2}+R M S_{Y}^{2}+R M S_{Z}^{2}}{3}}
$$

the components North, East, and Up are computed analogously (instead of $X, Y, Z$ ) and the final result (2) has to be the same.
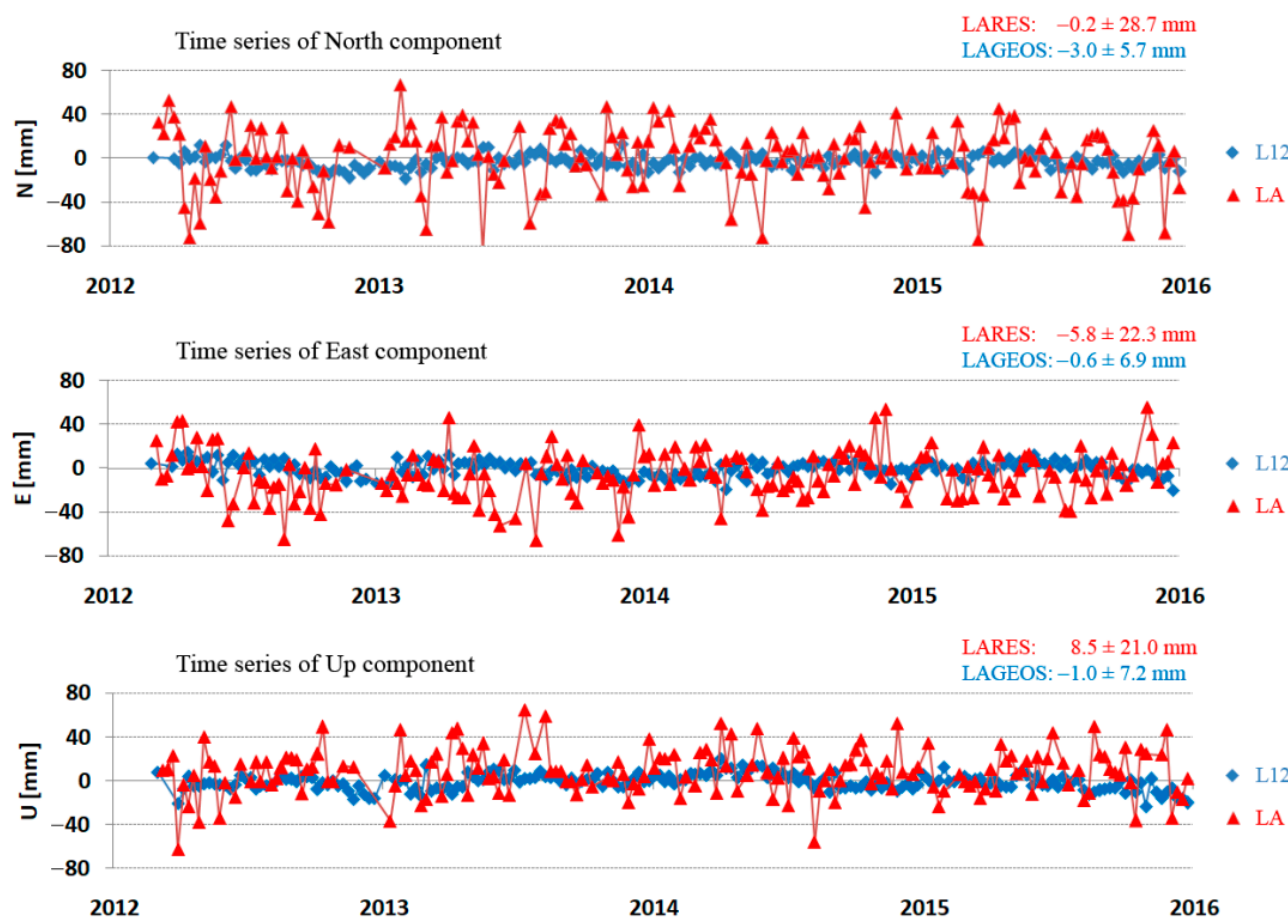

Figure 6. Time series of the North, East, and Up components for Yarragadee station (7090) for LARES (red) and LAGEOS (blue) in the period from 2012 to 2015.

The 3DRMS for each station and the three solutions is presented in Table 4 and Figure 7. The least accurate values were obtained for the LARES; much more accurate results for determining the position from this satellite for the European stations are clearly visible (7810, 7839, 7840, 7841, 7941, 8834). They are at the level of slightly weaker stations for LAGEOS. In contrast to the solution from all three satellites, as many as 10 stations have better results than the solution from LAGEOS alone, which indicates that the LARES + LAGEOS-1 + LAGEOS-2 solution after further research and analysis can be successfully used in the development of ITRF.

The precision of coordinate determination is defined by 3D standard deviation $(\sigma)$ as follows (3):

$$
\sigma=\sqrt{\frac{\bar{\sigma}_{X}^{2}+\bar{\sigma}_{Y}^{2}+\bar{\sigma}_{Z}^{2}}{3}}
$$

where $\bar{\sigma}_{X}, \bar{\sigma}_{Y}, \bar{\sigma}_{Z}$ are average standard deviations of the determined components $X, Y, Z$. The results presented in Table 4 and Figure 8 show a much better precision for a combined solution from three satellites for almost all stations, except Svetloe (1888), which confirms the previous conclusion that the solution for three satellites gives better results for coordinate determination. In the process of the standard deviation of the station coordinate determination, two parameters are crucial. First is the number of normal points per arc and second is the orbital RMS of these points. We have to bring into account also satellite trajectory. Both LAGEOS 1 and 2 have a significantly higher number of normal points 
(one and half times more than LARES), and the orbital RMS is the same as LARES (Figure 3), but the LAGEOS satellites have significantly better coverage of observations than LARES does. Therefore, the LAGEOS + LARES data can give better results than the LAGEOS data alone, mainly because it features a much higher number of normal points.

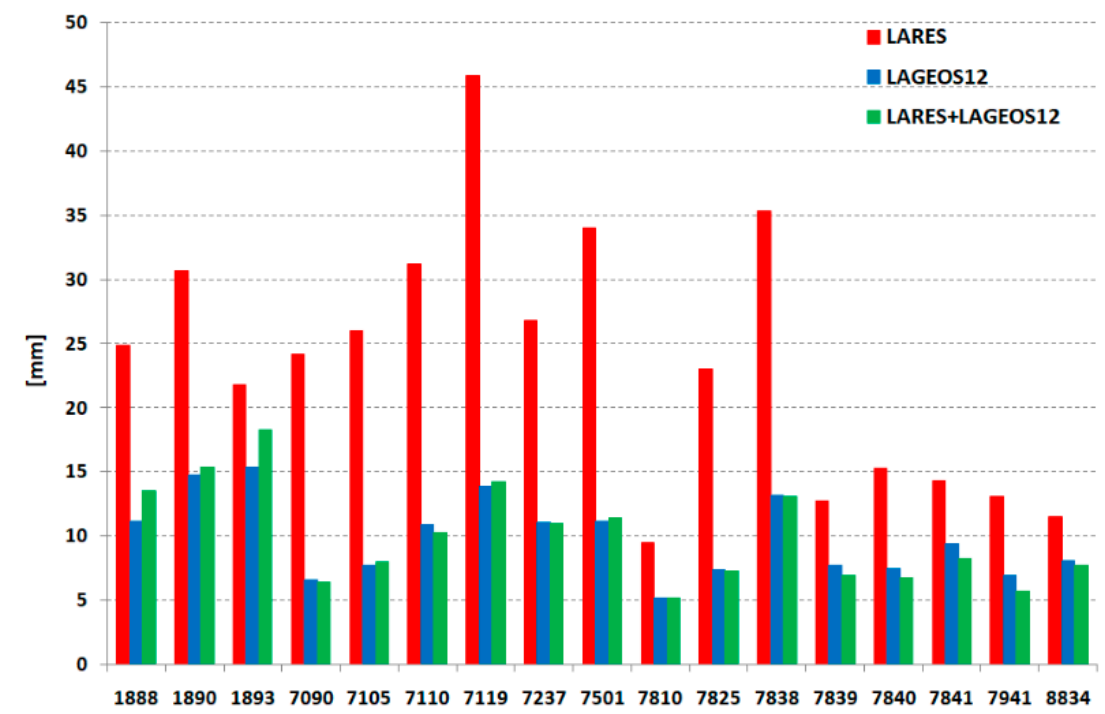

Figure 7. 3DRMS for each station for the three solutions: only LARES (red), LAGEOS-1 + LAGEOS-2 (blue), LARES + LAGEOS-1 + LAGEOS-2 (green).

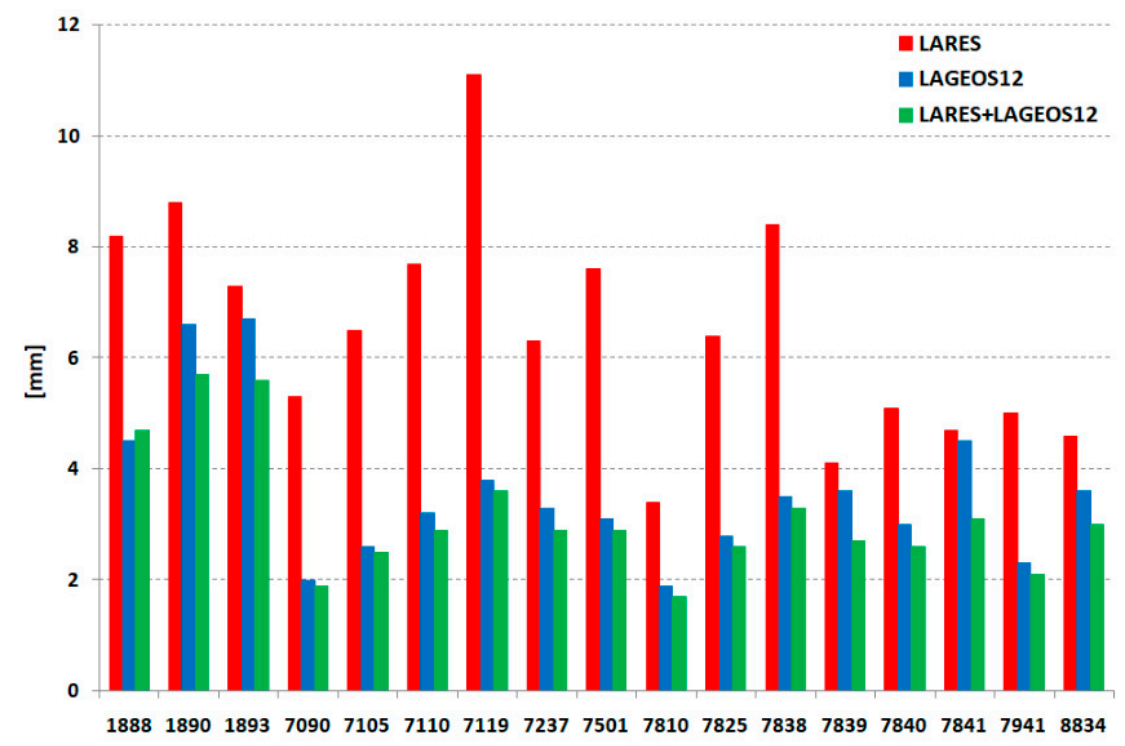

Figure 8. The average 3D precision for each station for three solutions: only LARES (red), LAGEOS-1 + LAGEOS-2 (blue), LARES + LAGEOS-1 + LAGEOS-2 (green).

Examples of the determined North, East, and Up components for each arc for LAGEOS and LARES + LAGEOS for the Zimmerwald and Yarragadee stations are presented in Figures 9 and 10, respectively. 


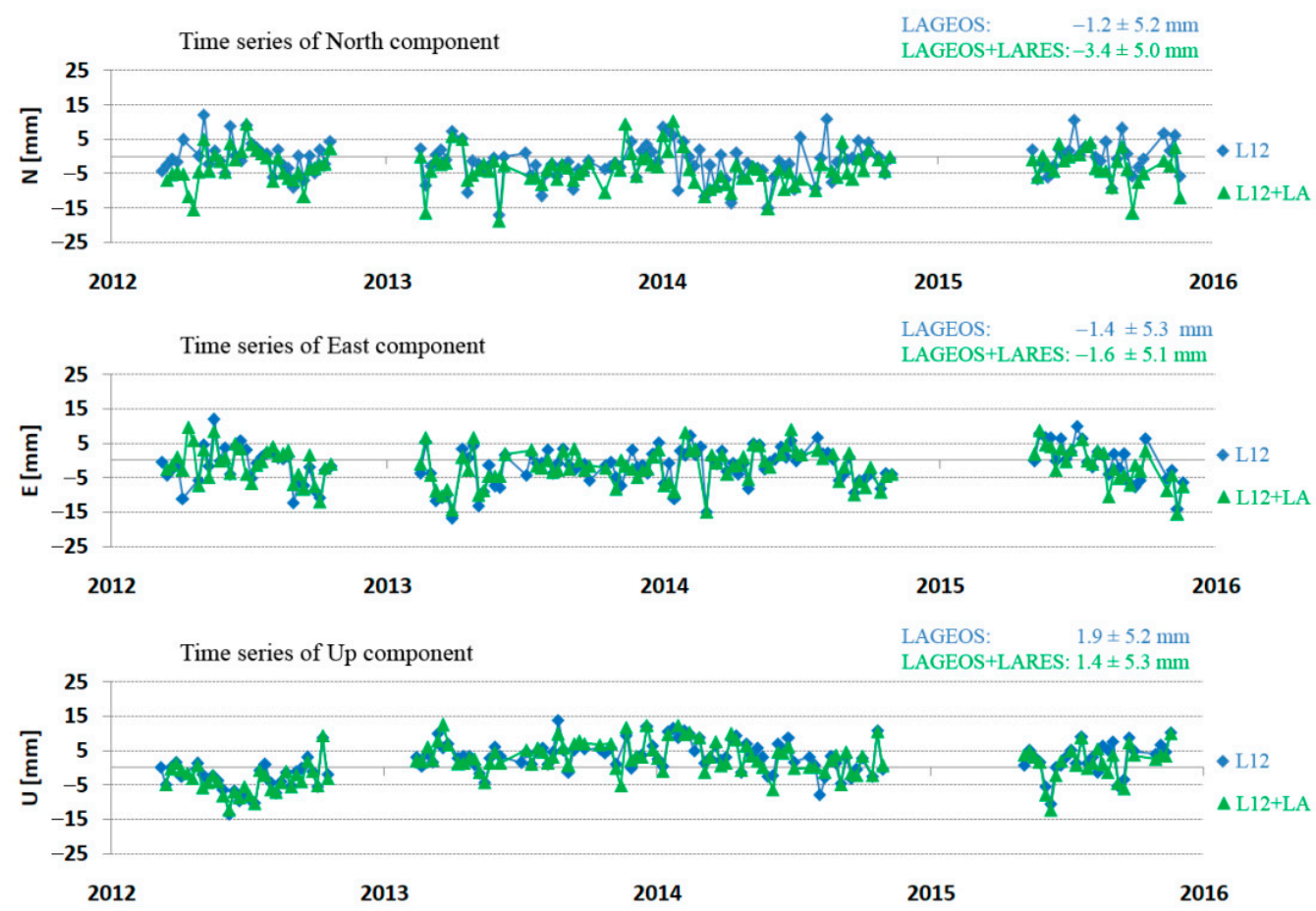

Figure 9. Time series of the North, East, and Up components for Zimmerwald station (7810) for LAGEOS + LARES (green) and LAGEOS (blue) in the period from 2012 to 2015.
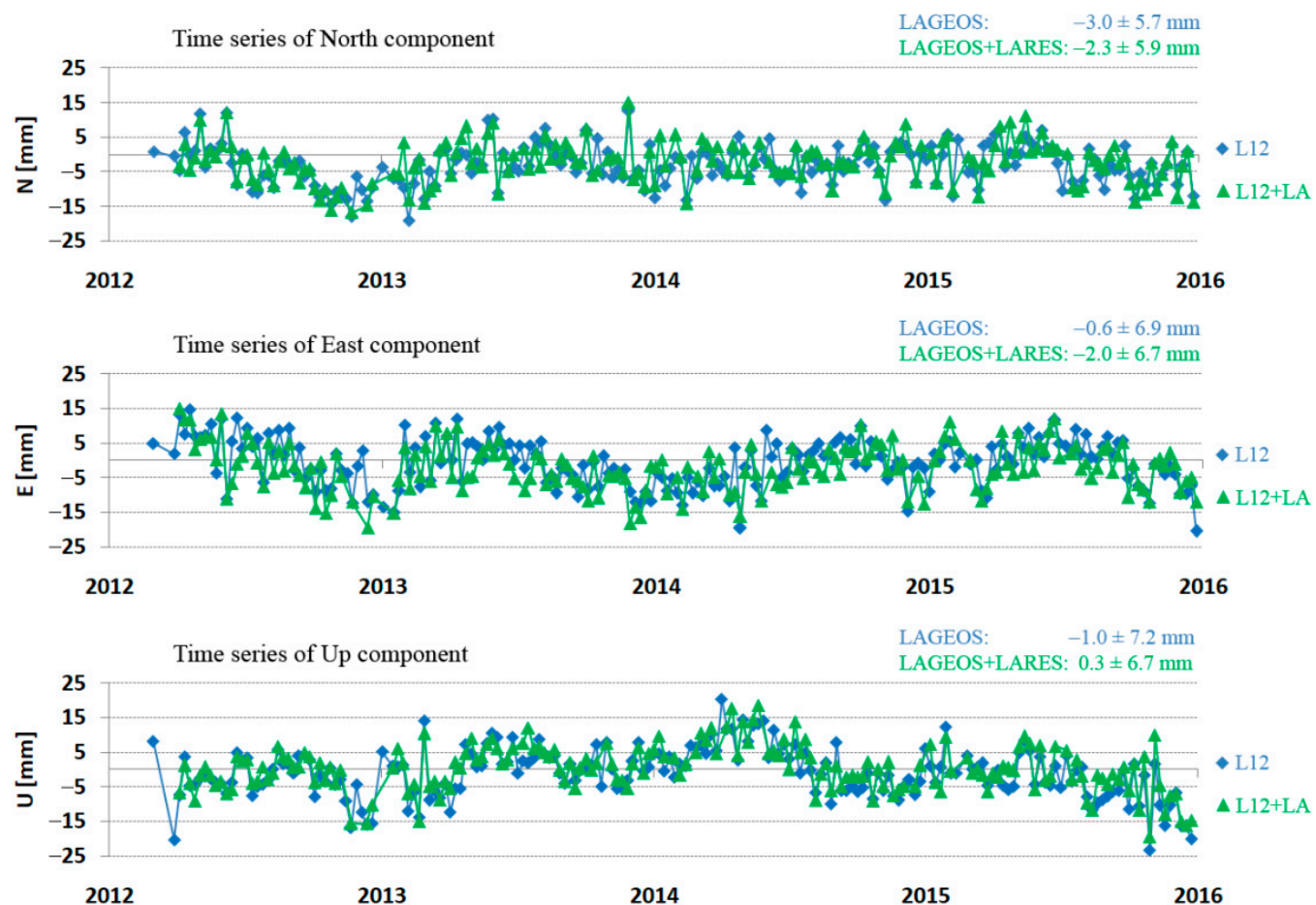

Figure 10. Time series of the North, East, and Up components for Yarragadee station (7090) for LAGEOS + LARES (green) and LAGEOS (blue) in the period from 2012 to 2015.

The presented results show good agreement for both solutions (L12 and L12 + LA) with an indication of small improvement for the solution from three satellites. For Yarragadee station (Figure 10), both solutions for all three components show an annual wave with amplitude of about $5 \mathrm{~mm}$. For each station, a comparison of average Range Bias and orbital RMS was performed for all three satellites: LARES, LAGEOS-1, and LAGEOS-2 (Table 5). 
It is worth emphasizing that high consistency of results for all three satellites for each station has been achieved.

\section{Conclusions}

We assessed the quality of station coordinates determined from the results of laser observations of the LARES satellite, noting that they are much lower than in the case of LAGEOS satellites. The station coordinates obtained from LARES are additionally dependent on the continental location of the station. Positive results were obtained for the results from combined solution of data from the LARES, LAGEOS-1, and LAGEOS-2. The results are even slightly better than those from LAGEOS. Very good agreement between average Range Bias and orbital RMS was found for all three satellites. The average orbital RMS for the LARES is $\pm 15.1 \mathrm{~mm}$ for all stations and is nearly the same as for the LAGEOS.

The accuracy of the station coordinates, defined as the average 3DRMS position for the LARES, changed from $9.5 \mathrm{~mm}$ to $45.9 \mathrm{~mm}$, while for the LAGEOS satellites it changed from $5.2 \mathrm{~mm}$ to $15.4 \mathrm{~mm}$, similar to the combined solution from three satellites (LARES, LAGEOS-1, LAGEOS-2) from $5.2 \mathrm{~mm}$ to $18.3 \mathrm{~mm}$ (Table 4). The station position accuracy for the LARES satellite is much better for European stations than for other stations. This is due to the large number of observations in Europe, as 8 of 17 stations carried out observations in Europe. On other continents, this number is exceedingly small (1-3 stations).

Position uncertainty, defined as the average 3D standard deviation of the coordinate determination for individual stations for LARES, is in the range of $3.4 \mathrm{~mm}$ to $11.1 \mathrm{~mm}$. For LAGEOS, it is much better at $1.9 \mathrm{~mm}$ to $6.7 \mathrm{~mm}$. For LARES + LAGEOS, the best result, it is from $1.7 \mathrm{~mm}$ to $5.7 \mathrm{~mm}$.

An important problem with the LARES observations is the lack of normal points in some weeks, especially in winter time, which causes the need to remove arcs due to the non-convergence iterative process. For some of the 40 stations there are too few normal points per week, which results in rejection of arcs due to the need to meet the criteria of quantity (>20 normal points per arc) and quality (<average 3 sigma). The result is that only $20 \%$ of all normal points for some stations will be left.

Will the results from many geodetic passive satellites (LAGEOS-1, LAGEOS-2, LARES, Etalon-1, Etalon-2, Ajisai, Starlette, Stella, Larets) [26] allow for better accuracy in determining the station coordinates? A larger number of normal points for each station can improve the results obtained only from LAGEOS satellites. This requires further studies to answer this question; it is an extremely important matter for the creation of subsequent International Terrestrial Reference Frames (ITRF) for release.

In the near future, there is a plan to launch the LARES 2 into an orbit similar to the LAGEOS satellites (altitude $5890 \mathrm{~km}$ ) [29], which will remove the effect of atmospheric drag, significantly reduce the number of Earth's gravity field coefficients, and also significantly reduce the influence of the Earth's albedo. This should ensure the quality of position determination at the level of the LAGEOS, and in the overall solution, due to the increase in the number of normal points, increase the accuracy of stations coordinates determination.

The combined solution from three satellites (LARES + LAGEOS-1 + LAGEOS-2) is better than the LAGEOS-only option. It is a good signal for including the LARES satellite and, in the future, LARES-2 to ITRF also, but this work needs additional activity of ILRS analysis centers.

Author Contributions: Conceptualization, S.S.; methodology, S.S.; software, P.M.; validation, P.L., S.S. and P.M.; formal analysis, S.S.; investigation, S.S. and P.L.; resources, P.M.; data curation, S.S.; Writing-Original draft preparation, S.S.; Writing-Review and editing, S.S. and P.L.; visualization, P.M.; supervision, S.S.; project administration, P.L.; funding acquisition, P.L. All authors have read and agreed to the published version of the manuscript.

Funding: This research received no external funding.

Institutional Review Board Statement: Not applicable.

Informed Consent Statement: Not applicable. 
Data Availability Statement: Input SLR data is available at the open access EUROLAS Data Center (EDC).

Acknowledgments: The authors wishes to thank the Goddard Space Flight Centre National Aeronautics and Space Administration for consent to use the GEODYN-II program, and to the International Laser Ranging Service stations for their continuous efforts to provide high quality SLR data. We are grateful to the anonymous reviewers for their efforts to improve our manuscript through constructive and careful remarks.

Conflicts of Interest: The authors declare no conflict of interest.

\section{References}

1. ESA, eoPortal Directory. LARES. Available online: https://earth.esa.int/web/eoportal/satellite-missions/1/lares (accessed on 10 November 2020).

2. Paolozzi, A.; Ciufolini, I.; Vendittozzi, C. Engineering and scientific aspects of LARES satellite. Acta Astronaut. 2011, 69, 127-134. [CrossRef]

3. Paolozzi, A.; Ciufolini, I. LARES successfully launched in orbit: Satellite and mission description. Acta Astronaut. 2013, 91, 313-321. [CrossRef]

4. Ciufolini, I.; Paolozzi, A.; Pavlis, E.C.; Koenig, R.; Ries, J.; Gurzadyan, V.; Matzner, R.; Penrose, R.; Sindoni, G.; Pani, C.; et al. A test of general relativity using the LARES and LAGEOS satellites and a GRACE Earth gravity model. Measurement of Earths dragging of inertial frames. Eur. Phys. J. C 2016, 76, 1-7. [CrossRef]

5. Pardini, C.; Anselmo, L.; Lucchesi, D.M.; Peron, R. On the secular decay of the LARES semi-major axis. Acta Astronaut. 2017, 140, 469-477. [CrossRef]

6. Ciufolini, I.; Paolozzi, A.; Pavlis, E.C.; Sindoni, G.; Ries, J.; Matzner, R.; Koenig, R.; Paris, C.; Gurzadyan, V.; Penrose, R. An improved test of the general relativistic effect of frame-dragging using the LARES and LAGEOS satellites. Eur. Phys. J. C 2019, 79, 1-6. [CrossRef]

7. Gurzadyan, V.G.; Ciufolini, I.; Khachatryan, H.G.; Mirzoyan, S.; Paolozzi, A.; Sindoni, G. On the Earth's tidal perturbations for the LARES satellite. Eur. Phys. J. Plus 2017, 132. [CrossRef]

8. Pucacco, G.; Lucchesi, D.M. Tidal effects on the LAGEOS-LARES satellites and the LARASE program. Celest. Mech. Dyn. Astr. 2018, 130, 66. [CrossRef]

9. Pavlis, E.C.; Paolozzi, A.; Paris, C.; Ciufolini, I.; Sindoni, G. Quality assessment of LARES satellite ranging data: LARES contribution for improving the terrestrial reference frame. In Proceedings of the 2nd IEEE International Workshop on Metrology for Aerospace, (MetroAeroSpace), Benevento, Italy, 4-5 June 2015; pp. 1-5. [CrossRef]

10. Sosnica, K.; Jäggi, A.; Thaller, D.; Beutler, G.; Dach, R. Contribution of Starlette, Stella, and AJISAI to the SLR-derived global reference frame. J. Geod. 2014, 88, 789-804. [CrossRef]

11. Pearlman, M.R.; Degnan, J.J.; Bosworth, J.M. The international laser ranging service. Adv. Space Res. 2002, 30, 135-143. [CrossRef]

12. Lejba, P.; Schillak, S. Determination of station positions and velocities from laser ranging observations to Ajisai, Starlette and Stella satellites. Adv. Space Res. 2011, 47, 654-662. [CrossRef]

13. Pavlis, D.E.; Luo, S.; Dahiroc, P.; McCarthy, J.J.; Lutchke, S.B. GEODYN II System Description; Hughes STX Contractor Report; Hughes STX: Greenbelt, MA, USA, 1998.

14. Torrence, M.H.; Klosko, S.M.; Christodoulidis, D.C. The construction and testing of normal point at goddard space flight center. In Proceedings of the 5th International Workshop on Laser Ranging Instrumentation, Herstmonceux, UK, 10-14 September 1984; Gaignebet, J., Ed.; Geodetic Institute, University of Bonn, 1985; Volume 2, pp. 506-516. Available online: https://ilrs.gsfc.nasa. gov/about/reports/workshop/lw05.html (accessed on 21 January 2021).

15. Pavlis, N.K.; Holmes, S.A.; Kenyon, S.C.; Factor, J.K. An earth gravitational model to degree; 2160:EGM2008. In Proceedings of the 2008 General Assembly of the European Geoscience Union, Vienna, Austria, 13-18 April 2008.

16. IERS Conventions (2003); IERS Technical Note No. 32; McCarthy, D.D.; Petit, G. (Eds.) International Earth Rotation and Reference Systems Service; Bundesamt für Kartographie und Geodäsie: Frankfurt am Main, Germany, 2004.

17. Ray, R.D. A Global Ocean Tide Model from TOPEX/POSEIDON Altimetry: GOT99.2; NASA/TMm1999-200478; Goddard Space Flight Center: Greenbelt, MD, USA, 1999; pp. 1-66.

18. Standish, E.M.; Newhall, X.X.; Williams, J.G.; Folkner, W.F. JPL Planetary and Lunar Ephemerides DE403/LE403; JPL IOM; California Institute of Technology: Pasadena, CA, USA, 1995; Volume 31, pp. 10-127.

19. IERS Conventions (2010); IERS Technical Note No. 36; Petit, G.; Luzum, B. (Eds.) International Earth Rotation and Reference Systems Service; Bundesamt für Kartographie und Geodäsie: Frankfurt am Main, Germany, 2010.

20. Hedin, A.E. MSIS-86 thermospheric model. J. Geophys. Res. 1987, 92, 4649-4662. [CrossRef]

21. Altamimi, Z.; Rebischung, P.; Metivier, L.; Collilieux, X. ITRF2014: A new release of the International Terrestrial Reference Frame modeling nonlinear station motions. J. Geophys. Res. Solid Earth 2016, 121, 6109-6131. [CrossRef]

22. ILRS. SLRF2014 Station Coordinates. 2017. Available online: ftp://ftp.cddis.eosdis.nasa.gov/pub/slr/products/resource/SLRF2 014_POS+VEL_2030.0_170605.snx (accessed on 22 November 2019). 
23. Mendes, V.B.; Prates, G.; Pavlis, E.C.; Pavlis, D.E.; Langley, R.B. Improved mapping functions for atmospheric refraction in SLR. Geophys. Res. Lett. 2002, 29, 53-1-53-4. [CrossRef]

24. Mendes, V.B.; Pavlis, E.C. High-accuracy zenith delay prediction at optical wavelengths. Geophys. Res. Lett. 2004, 31 , L14602. [CrossRef]

25. Otsubo, T.; Sherwood, R.A.; Appleby, G.M.; Neubert, R. Center-of-mass corrections for sub-cm-precision laser-ranging targets: Starlette, Stella and LARES. J. Geod. 2015, 89, 303-312. [CrossRef]

26. Sośnica, K. Determination of Precise Satellite Orbits and Geodetic Parameters Using Satellite Laser Ranging. Ph.D. Thesis, University of Bern, Bern, Switzerland, 7 April 2014.

27. Borkowski, K.M. Accurate algorithms to transform geocentric to geodetic coordinates. Bull. Geod. 1989, 63, 50-56. [CrossRef]

28. Alothman, A.O.; Schillak, S. Recent results for the Arabian plate motion using satellite laser ranging observations of Riyadh SLR station to LAGEOS-1 and LAGEOS-2 satellites. Arab. J. Sci. Eng. 2014, 39, 217-226. [CrossRef]

29. Paolozzi, A.; Sindoni, G.; Felli, F.; Pilone, D.; Brotzu, A.; Ciufolini, I.; Pavlis, E.C.; Paris, C. Studies on the materials of LARES 2 satellite. J. Geod. 2019, 93, 2437-2446. [CrossRef] 